\title{
Болезнь Вильсона -
}

\section{гепатоцеребральная Аистрофия}

\section{Я. С. Циммерман}

Пермский государственный медицинский университет им. акаА. Е. А. Вагнера, Пермь, Россия

Ключевые слова: болезнь Вильсона (гепатоцеребральная Аистрофия), дефиниция, этиология, патогенез, Аиагностика, мечение

Основное, подчас решающее значение из внутренних причин болезней имеют факторы наследственного преАрасполоЖеНия и инАИвиАУальность. И. В. Аавыдовский (1887-1968) [3].

\section{Дефиниция}

До сих пор не существует однозначного определения болезни Вильсона. Приведем несколько наиболее удачных, как нам представляется, ее определений.

Болезнь Вильсона, или гепатоцеребральная дистрофия, - это редкое, генетически обусловленное заболевание с аутосомно-рецессивным типом наследования, в основе которого лежит нарушение обмена меди с избыточным ее накоплением, преимущественно в печени и в центральной нервной системе [5].

Болезнь Вильсона - это редко встречающееся наследственно детерминированное аутосомно-рецессивное заболевание, характеризующееся избыточным накоплением меди в печени, головном мозге, почках и других органах [12].

Болезнь Вильсона, или гепатолентикулярная дегенерация, - это редкое, наследственно обусловленное заболевание, в основе которого лежит нарушение обмена меди с ее накоплением в органах-мишенях: печени, головном мозге (чечевицеобразных ядрах, подкорке и коре), с коричнево-зеленой пигментацией края роговицы и поражением почек [7].

В Международную классификацию болезней и проблем, связанных со здоровьем, 10-го пересмотра (МКБ-10), 1995 года болезнь Вильсона включена под шифром (кодом) E83.0 [12].

\section{Терминология}

Термин «болезнь Вильсона» (Wilsons disease) происходит от фамилии британского невролога (Samuel Alexander Kinnier Wilson, 1878-1937), описавшего эту болезнь в 1912 году. Однако намного раньше ее описание было представлено двумя немецкими учеными: Karl Friedrich Otto Westphal (1833-1890) - в 1883 году (Arch. Psychiatr, 1883; 14: 87-134) и Adolf Strumpel (1853-1925) - в 1898 году (Dtsch. Zschr. Nervenkrankh., 1998; 12: 115-149), в связи с чем ее первоначально именовали болезнью Вестваля Штрюмпеля [20]. Причина этого расхождения состояла в том, что сначала болезнь Вестваля Штрюмпеля и болезнь Вильсона (в русской транскрипции фамилию «Wilson» в переводе с английского следует обозначать как «Уильсон») рассматривали как два самостоятельных заболевания, и только в 1920 году Spielmayer и Hall доказали, что болезнь Вестваля - Штрюмпеля - это лишь один из вариантов (форм) болезни Вильсона. Впоследствии удалось установить, что первое описание этой болезни было представлено еще раньше - в 1854 году (Frerichs) [20].

В нашей стране до сих пор часто болезнь Вильсона именуют «болезнью Вильсона - Коновалова» (Н. В. Коновалов (1900-1966), российский невролог). Это связано с тем, что в послевоенные годы (1949-1953) в СССР официальными властями была инициирована очередная шумная политическая кампания под лозунгами «борьбы с космополитизмом и преклонением перед иностранщиной», которая в медицинской науке вылилась в поиск, во что бы то ни стало, приоритета отечественных авторов в различных разделах медицины. Именно в то время появились без достаточных научных обоснований «двойные» эпонимические термины многих клинических симптомов и болезней: симптомы Щеткина - Блюмберга, Грекова - Ортнера, Виноградова - Дюрозье, Георгиевского - Мюсси и много др. Одним из них и стал термин «болезнь Вильсона - Коновалова», которым нигде в мире не пользуются. Мы полагаем, что следует использовать международно признанный термин - болезнь Вильсона [13].

\section{Синонимы}

В медицинской литературе можно встретить множество других наименований болезни Вильсона: болезнь Вестваля - Штрюмпеля - Вильсона - гепатолентикулярная дегенерация (degeneration hepatolenticularis);болезньВильсона - гепатоцеребральная дистрофия (dystrophia hepatocerebralis); нейрогепатическая дегенерация и др. Однако чаще всего 
пользуются эпонимическим термином - болезнь Вильсона [20].

\section{Распространенность}

Большинство авторов указывают, что частота болезни Вильсона составляет 1:100 000 популяции, это редкое заболевание [2]. Болезнь обычно манифестирует в возрасте 8-18 лет, а иногда и раньше, но в случаях, когда в начальной стадии она протекает латентно или малосимптомно, ее диагностируют в более старших возрастных группах, нередко уже при сформировавшемся циррозе печени. Несколько чаще болезнь Вильсона встречается у мужчин, чем у женщин [2].

\section{Этиология и патогенез}

Среди этиологических факторов болезни Вильсона целесообразно различать внешнесредовые и внутренние факторы. В разное время в качестве возможных внешнесредовых этиологических факторов фигурировала инфекция - бактериальная и вирусная, а также микробная интоксикация, однако доказать инфекционное происхождение болезни Вильсона так и не удалось [14].

В настоящее время установлено, что основное значение в происхождении болезни Вильсона принадлежит наследственности - генетическим факторам.

Болезнь Вильсона - это наследственно-детерминированное заболевание с аутосомно-рецессивным типом наследования, в основе которого лежит нарушение выведения меди $(\mathrm{Cu})$ из печени с желчью и ее избыточное накопление в органах и тканях, прежде всего в печени и в головном мозге (в чечевицеобразных ядрах, в подкорке и в коре), - это своеобразная «врожденная ошибка обмена меди» $[5,10,14,16,19]$.

Ген болезни Вильсона расположен на длинном плече 13-й хромосомы. Он кодирует структуру медьтранспортирующей АТФазы Р-типа (АТР7В), локализующейся в транспортной сети аппарата Гольджи и в мембранах митохондрий, а также на каналикулярной мембране гепатоцитов $[1,10,14,18,25]$. Важным в функциональном отношении являются: 1) 6 медьсвязывающих доменов; 2) домен, высвобождающийся при гидролизе АТФ, который участвует в транскрипции энергии, и 3) АТФ-связывающий домен.

Ген болезни Вильсона часто подвергается мутациям (их известно около 100), из которых наиболее важна мутация H1069Q [10].

Вместе с пищей в организм человека ежедневно поступает 2-5 мг меди, которая, всасываясь в кишечнике, транспортируется по воротной вене в печень, где соединяется в аппарате Гольджи с иерулоплазмином - особым сывороточным белком из фракции $\alpha$-глобулинов, принадлежащим к группе металлопротеидов, который содержит медь и обладает свойствами окислительного фермента. Он синтезируется в печени и регулирует транспорт меди в организме человека. Затем медь экскретируется в кишечник вместе с желчью. При болезни Вильсона абсорбция меди в кишечнике повышается (до 1,2-1,7 мг/сут), a ее экскреция с желчью, напротив, - снижается (до
0,6 мг/сут), что является следствием резкого снижения или полного отсутствия гена болезни Вильсона. При этом медь в повышенном количестве депонируется в кровяном русле, в ткани печени, головном мозге, роговице глаза, почках и других органах. Так, содержание меди в ганглиях головного мозга повышается в 10 раз.

Повышенная концентрация меди в органах и тканях вызывает блокаду сульфгидрильных (SH) групп ряда ферментов, нарушая метаболические процессы в печени и вызывая интоксикацию, а также обусловливает энергетическое голодание головного мозга $[7,28]$.

Медь служит активатором инсулина, обусловливая расстройство углеводного обмена - гиперинсулинизм.

Кроме того, медь является прооксидантом, поэтому ее избыточное накопление в гепатоцитах проявляется в повышенной генерации продуктов свободнорадикального окисления липидов, снижении содержания антиоксидантов и запасов глутатиона в печени, что, как следствие, приводит к цитолизу (некрозу) гепатоцитов. При этом медь высвобождается из печеночных клеток, накапливаясь в повышенном количестве в кровяном русле, и откладывается в органах-мишенях $[10,16,25]$.

В специальном исследовании семейный (наследственный) характер болезни Вильсона был отмечен в 80 случаях из 175 обследованных семей больных. При этом была установлена полная конкордантность по болезни Вильсона однояйцевых близнецов. Была доказана также высокая пенетрантность гена болезни Вильсона $[7,16]$.

Носителями патологического аллеля являются гетерозиготы, составляющие 1\% практически здоровых лиц, - у них выявляют аномалии метаболизма меди. У гетерозиготных родителей рождается $25 \%$ больных с болезнью Вильсона, $25 \%$ здоровых детей и $50 \%$ - гетерозиготных, у которых генотип подобен родительскому.

\section{Клиника}

Клиническая картина болезни Вильсона отличается полиморфизмом. Чаще всего (в 40-65\% случаев) заболевание дебютирует с поражения печени, развивающегося в возрасте 5-18 лет; реже (в 30\%) с неврологических и психических расстройств. Значительно реже возможно начало болезни с гемолитического криза и гемолитической анемии (форма Керара). Течение болезни может быть фульминантным и медленно прогрессирующим.

Абдоминальная форма болезни Вильсона может проявляться фульминантной печеночной недостаточностью, острым и хроническим гепатитом с исходом в цирроз печени, характеризующийся портальной гипертензией и отечно-асцитическим синдромом, а также кровотечением из варикозно расширенных вен пищевода и желудка. В 1\% случаев возможно начало болезни с поражения почек, протекающего с проксимальной канальцевой дисфункцией (синдром Фанкони), повышенной экскрецией кальция с мочой, с гиперфосфатурией и нарушением 
ее ацидофикации, что способствует развитию мочекаменной болезни и нефрокальциноза; IgA-нефропатии или хронического гломерулонефрита. Иногда наблюдается эндокринная дисфункция с признаками гипогонадизма (олиго- и аменорея, бесплодие, признаки гирсутизма) $[1,2,4,5,8,12,14,21,25]$.

Фульминантная печеночная недостаточность протекает с быстро прогрессирующей желтухой, острой печеночной недостаточностью, энцефалопатией, умеренной спленомегалией, внутрисосудистым гемолизом с последующей гемолитической анемией (до 50 г/л и менее); тромбоцитопенической пурпурой с выраженным геморрагическим синдромом; гипербилирубинемией за счет конъюгированной и неконъюгированной его фракций при низком уровне щелочной фосфатазы и значительном повышении содержания свободной меди в сыворотке крови, что является основной причиной гемолитического криза и внутрисосудистого гемолиза (у 15\% больных). При этом наблюдается гемоглобинурия и возможно развитие острой почечной недостаточности, а соотношение «щелочная фосфатаза: билирубин» снижается до 2,0/100\% [9].

В короткие сроки фульминантная печеночная недостаточность приводит к летальному исходу, который может быть предотвращен только срочной трансплантацией печени $[1,14,19]$. В качестве провоцирующих факторов развития фульминантной печеночной недостаточности могут выступать острый вирусный гепатит с репликацией вируса в печени и вирус герпеса 6-го типа, поражающий ткань печени $[17,22,31]$. Хронический гепатит при болезни Вильсона характеризуется высокой активностью, выраженной желтухой и некрозом гепатоцитов, о чем свидетельствует существенное повышение содержания в сыворотке крови ферментов цитолиза (аспартатаминотрансферазы (АсАТ) и аланинаминотрансферазы (АлАТ)), ферментов холестаза (щелочной фосфатазы (ЩФ), $\gamma$-глутамилтранспептидазы, лейцинаминопептидазы), гипергаммаглобулинемия и быстрая трансформация в цирроз печени с характерными для него портальной гипертензией, асцитом и периферическими отеками $[1,2,14,25,27,30]$. Гистологически при этом определяют наличие микровезикулярной жировой дистрофии и коагуляционный некроз гепатоцитов [7].

В сравнительно редких случаях в начальном периоде болезни Вильсона встречается латентное или малосимптомное течение со «стертой» клинической симптоматикой, проявляющейся легкой желтухой, астеническим синдромом, умеренным отклонением от нормы функциональных печеночных проб (АсAТ и АлАТ, ЩФ и др.). В этих случаях болезнь удается диагностировать только на стадии сформировавшегося цирроза печени [2].

Внепеченочные поражения при болезни Вильсона проявляются, прежде всего, неврологическими и психическими расстройствами.

Они развиваются обычно позднее - в возрасте 20-30 лет и проявляются экстрапирамидными расстройствами: «порхающим тремором» вытянутых рук и всего тела, который усиливается при эмоциональном напряжении и тревожном состоянии больных; гипомимией («маскообразное» лицо); гиперсаливацией; монотонной, как бы затрудненной речью, мышечной ригидностью и хореоатетозными торсионно-спастическими гиперкинезами в виде «бьющихся крыльев», изменением тембра голоса и дисфонией $[1,4,7,14,19]$. При тяжелой форме болезни Вильсона описан синдром Гийена - Барре (Gillain - Barre): полирадикулоневропатия с периферическим тетрапарезом $[9,24]$.

Психические расстройства при болезни Вильсона проявляются изменениями в эмоциональной сфере и поведении больных; эпилептиформными припадками; шизофреноподобной симптоматикой; постепенным снижением интеллекта $[1,2,4,14,29]$.

Весьма характерно поражение глаз при болезни Вильсона: появление роговичного «медного кольца» Кайзера - Флейшера (Kayser - Fleischer) - зелено-желто-буроватого окрашивания на границе склеры и роговицы. Реже встречается катаракта в виде «подсолнуха» [9].

В части случаев наблюдается поражение почек, протекающее с микро- и макрогематурией, протеинурией, аминоацидурией, глюкозурией, отечным синдромом, повышением содержания креатинина в сыворотке крови, а также проксимальной почечной дисфункцией - синдромом Фанкони (в 1\% случаев). Кроме того, возможны гиперурикозурия со склонностью к нефролитиазу; нефротический и отечный синдромы; хронический гломерулонефрит $[1,2,8,14]$.

Поражения суставов при болезни Вильсона протекают с артралгией, дизартрией, сгибательными контрактурами, изменениями в позвоночнике, коленных суставах; остеопорозом и остеомаляцией.

Нередко наблюдается поражение системы крови: острый внутрисосудистый гемолиз, гемолитическая анемия, развивающаяся после гемолитического криза [21].

У некоторых больных с болезнью Вильсона наблюдаются признаки гипогонадизма, проявляющиеся нарушениями менструального цикла, аменореей, бесплодием [4].

Кожный синдром проявляется васкулитами, кожной, сосудистой и тромбоцитопенической пурпурой $[4,8]$.

Болезнь Вильсона может осложняться интеркуррентными инфекциями.

\section{Классификация}

Общепризнанной международной классификации болезни Вильсона не существует. Мы разработали клиническую классификацию этого заболевания, которая представлена ниже [12].

Клиническая классификация болезни Вильсона

I. Латентная (или малосимптомная) стадия.

II. Стадия клинических проявлений (рис. 1).

1. Поражения печени, острый и хронический гепатит; цирроз печени; фульминантная печеночная недостаточность.

2. Неврологические расстройства: а) ранние - монотонная, затрудненная речь; гиперсаливация; атаксия; нарушение координации движений; б) поздние - экстрапирамидные расстройства; мышечная 
ригидность; эпилептиформные припадки; тремор; гипомимия; гиперкинезы; дисфония.

3. Психические нарушения: эмоциональные расстройства; изменение поведения; эпилептиформные припадки; шизофреноподобная симптоматика.

4. Поражение глаз: кольцо Кайзера - Флейшера; катаракта.

5. Поражение почек: микро- и макрогематурия, протеинурия, аминоацидурия, гиперкальциурия, гиперфосфатурия, глюкозурия; нефролитиаз; синдром Фанкони; нефротический синдром; хронический гломерулонефрит.

6. Поражение суставов: артралгии; остеопороз и остеомаляция; сгибательные контрактуры.

7. Поражение системы крови: острый внутрисосудистый гемолиз; гемолитическая анемия.

8. Поражение кожных покровов: васкулиты; кожная, сосудистая и тромбоцитопеническая пурпура.

III. Терминальная стадия [12].

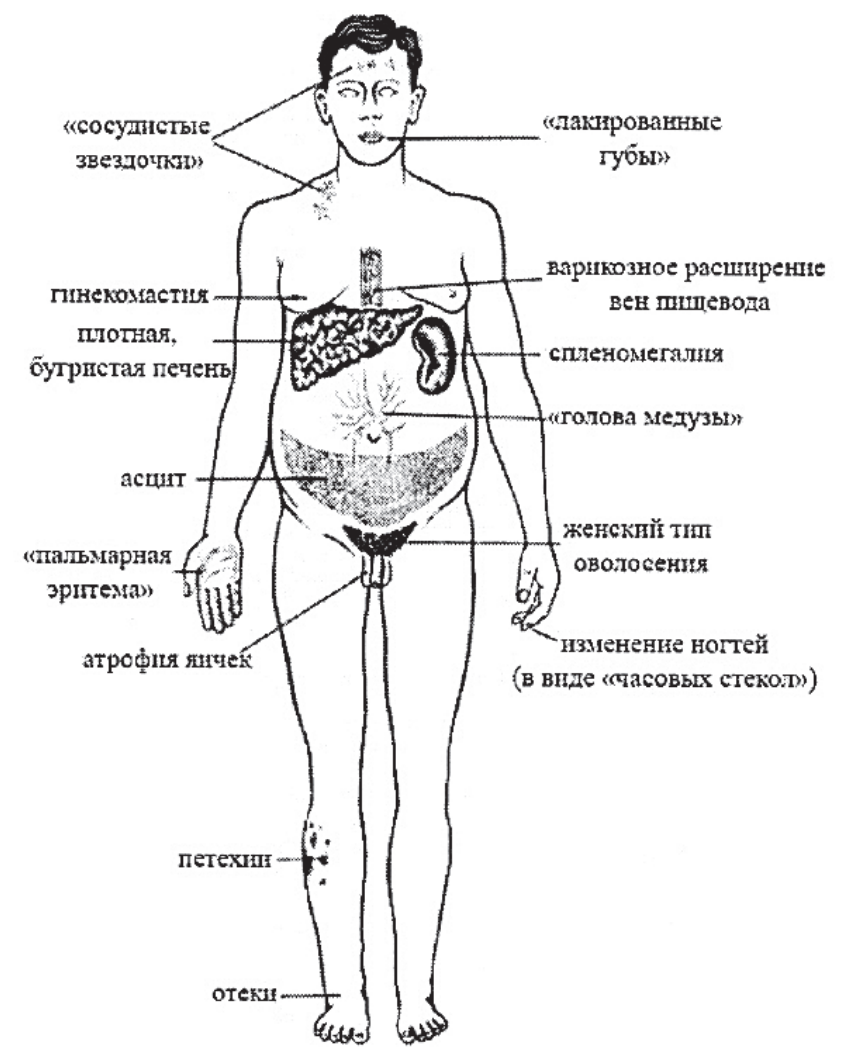

Рис. 1. Клинические проявления болезни Вильсона.

\section{Диагностика}

Многочисленные «маски» болезни Вильсона и (в небольшой части случаев) малосимптомное течение начальной стадии заболевания затрудняют ее своевременную диагностику.

Наиболее частым и надежным признаком болезни Вильсона служит наличие кольца Кайзера - Флейшера на роговище глаза (определяется в 90\% случаев и может считаться патогномоничным симптомом): исследование с помощью щелевой лампы.

Отдельные авторы указывают на «триаду» диагностических признаков: 1) кольцо Кайзера Флейшера; 2) желтуха; 3) гемолитическая анемия $[1,5,7,10]$.
Выраженная гемолитическая анемия развивается вследствие некроза гепатоцитов, депонировавших медь, которая, высвобождаясь, индуцирует гемолиз эритроцитов [30].

Диагностическое значение имеет также семейный анамнез: наличие аналогичного заболевания у кровных родственников первой степени родства. При генетическом исследовании можно определить мутацию гена $A T P 7 B$, ответственного за развитие болезни Вильсона [18].

Важное диагностическое значение имеют характерные нервно-психические расстройства и развитие фульминантной печеночной недостаточности.

Лабораторные исследования позволяют установить: 1) снижение уровня церулоплазмина в сыворотке крови (на 35-65\%) у 95\% больных - до 0-200 мг/л (при норме (355 \pm 100$)$ мг/л); 2) повышение содержания свободной меди в крови (до 300 мкг/л и более) и в биоптатах печени (при окраске орсеином и роданином) - более 250 мг/г сухой массы (при норме $<50$ мг/г); 3) в биоптатах печени, кроме того, можно определить присутствие липофусиина, жировую дистрофию печени, фиброз и цирроз печени; 4) уровень ЩФ, как правило, снижен, несмотря на наличие желтухи; умеренно повышено содержание ферментов цитолиза: больше АсАТ, чем АлАТ.

Выделение меди с мочой до начала лечения $\mathrm{D}$-пеницилламином чаще всего (у 65\% больных) снижено (на $50 \%$ и более), а при систематическом приеме D-пеницилламина ее выделение с мочой увеличивается до 50 раз(!) (норма: < 50мкг/сут) гиперкупрурия.

Инструментальная диагностика. Магнитно-резонансная томография выявляет изменения в базальных ядрах головного мозга.

При сцинтиграфическом исследовании биоптатов печени с радиоактивной медью, которая поглощается печеночной тканью, через 2 и 24 ч после внутривенного введения радионуклида соотношение радиоактивности печени составляет 0,2-0,3 (при норме 1,4-9,0).

Всем больным целесообразна консультация психоневролога.

Дифференциальную диагностику следует проводить с гепатоцеребральными синдромами при вирусных и других заболеваниях печени; с рассеянным склерозом; энцефалитом; дрожательным параличом (болезнью Паркинсона).

\section{Лечение}

Лечебные мероприятия при болезни Вильсона направлены в первую очередь на предотвращение необратимых изменений в органах и тканях путем воздействия на врожденные дефекты билиарной секреции меди [6].

При установлении диагноза болезни Вильсона лечение нужно назначать немедленно. При этом необходимо следить за тем, чтобы уровень свободной меди в сыворотке крови во время лечения не поднимался выше 20 мкг/дл. Лечение должно быть непрерывным и пожизненным, поскольку это неизлечимая болезнь. 
Лечебное питание (диета № 5 по М. И. Певзнеру) с повышенным содержанием белка. Необходимо исключить из пищевого рациона содержащие медь продукты: ракообразные (раки, крабы и др.), баранину, куриное и утиное мясо, рыбу, бобовые, орехи, чернослив, какао, шоколад, мед, перец [7].

Фармакотерапия. Основным препаратом для лечения болезни Вильсона по-прежнему (уже в течение более 50 лет!) является D-пеницилламин в индивидуально подобранной дозе - в пределах от 1,5 до 4 г/сут; оптимальной дозой считается $0,9-1,2$ г/сут $[7,14,10,25]$.

Лечение D-пеницилламином - это патогенетическая терапия, способствующая выведению избыточного количества меди из организма.

При многолетнем лечении D-пеницилламином возможны различные побочные эффекты: развитие нефротического синдрома; синдрома Гудпасчера; интерстициального гломерулонефрита; агранулоцитоза; тромбо- и лимфопении; фиброзирующего альвеолита (за счет нарушения синтеза коллагена); волчаночноподобного синдрома; апластической анемии; неврита зрительного нерва; фолликулярного конъюнктивита; пемфигуса; афтозного стоматита; кожной эритемы; глубоких язв голени, фурункулеза и др. $[7,11,26,27]$.

Несмотря на столь обширный перечень побочных эффектов, большинство больных переносят многолетний курс лечения D-пеницилламином вполне удовлетворительно.

P. Ferenci [10] в качестве альтернативы D-пеницилламину предлагает лечение триентином (trientin), также способствующим выведению избыточного количества меди из организма больного; доза 1,01,5 г/сут. По его данным, эффективность триентина при болезни Вильсона не уступает D-пеницилламину, но у него меньше побочных явлений.

D-пеницилламин, как и триентин, - это хелатируюшие медь соединения.

Ценным методом лечения болезни Вильсона (особенно в случае непереносимости D-пеницилламина) является применение препаратов изинка (сульфата или ацетата). Цинк конкурирует с медью за связывание с белком-переносчиком на мембране эритроцитов и тем самым блокирует транспорт меди, которая выводится с калом вместе с десквамированными эпителиоцитами. Доза: 75-200 мг/сут 3 раза в сутки за 30 мин до приема пищи, длительно. Это недорогой, безопасный и достаточно эффективный метод лечения $[1,7,14]$.

При развитии фульминантной печеночной недостаточности - наиболее грозного проявления болезни Вильсона - используют плазмаферез, альбуминовый диализ, гемофильтрацию, перитонеальный диализ, а при их неэффективности возникает необходимость в срочной ортотопической аллотрансплантации печени $[1,5,7,14,15,19]$.

Адъювантная (вспомогательная) терапия. Ряд авторов считает оправданным назначение больным с болезнью Вильсона унитиола, который содержит две сульфгидрильные (SH) группы и способен восстанавливать функции ферментных систем печени, обладает детоксицирующим действием [5, 7]. Доза унитиола: 5-10 мл 5\% раствора внутримышечно ежедневно или через день, 25-30 дней.

Близок по механизму действия к унитиолу зарубежный препарат «БАЛ - британский антилюизит» (димеркапрол-2,3-димеркаптопропанол), но он более токсичен [7]. Он вводится внутримышечно в дозе $1,25-2,5$ мг/кг 2 раза в сутки в течение 20 дней; проводится несколько курсов с перерывом в 20 дней.

При поражении печени у больных с болезнью Вильсона оправдано применение гепа-мери (L-орнитина-L-aспартата), особенно при наличии гепатодепрессивного (гепатопривного) синдрома, в дозе 500 мг/сут в 500 мл физраствора, внутривенно капельно (4-8 капель в минуту).

Безусловно полезен прием антиоксидантов: витамина $E$ ( $\alpha$-токоферола ацетат): $10 \%$ масляный раствор, 1 мл (100 мг) внутрь по 1 капле, в течение 2-3 месяцев.

Более эффективен комбинированный антиоксидант - антиоксикапс, который содержит селен (15 мг), аскорбиновую кислоту (100 мг), $\alpha$-токоферола ацетат (30 мг) и Р-каротин (20 мг). Его принимают внутрь по 1 капсуле в сутки после еды в течение 2-3 месяцев.

При асиите и периферических отеках назначают мочегонные средства: спиронолактоны (альдактон, верошпирон) по 100-200 мг 2-3 раза в сутки или амилорида гидрохлорид по 5-10 мг/сут - до полной ликвидации асцита и отеков. Используют также фуросемид (лазикс) по 40 мг внутрь 1 раз в сутки внутримышечно или внутривенно медленно струйно: по 20-60 мг 1 раз в сутки.

Болезнь Вильсона неизлечима, но при своевременном и непрерывном (пожизненном) лечении самочувствие больных долгие годы остается стабильным, и они длительное время сохраняют жизнь.

При неэффективности медикаментозного лечения единственным методом спасения их жизни является трансплантация печени. 


\section{Митература:}

1. Болезни печени и желчевыводящих путей / ПоА реА. В. Т. Ивашкина. - М., 2002. - С. 220-235.

2. Болезнь Вильсона (клиническое наблюдение) / М. В. Маевская, А. В. Ведерникова, В. Т. Ивашкин [и Ар.] // Российск. журн. гастроэнтерол., гепатол. и колопроктол. - 2002. - № 5. - С. 20-22.

3. Аавыдовский И. В. Проблемы причинности в медицине. Этиология / И. В. Аавыдовский. - М., $1962-$ $176 \mathrm{c}$.

4. Киинические варианты гепатоцеребральной Аистрофии / Г. В. Сухарева, С. А. Шепелева, Т. В. Нилова [и Ар.] // Экспер. и клин, гастроэнтерол. - 2003. № 1. - C. 133-134.

5. Лопаткина Т. Н. Болезнь Вильсона - Коновалова / Т. Н. Аопаткина // Руководство по гастроэнтерологии / Под реА. Ф. И. Комарова, С. И. Рапопорта. М., 2010. - С. 579-583.

6. Майер К.-П. Гепатит и послеАствия гепатита / К.-П. Майер; пер. с нем. - М., 1999. - С. 252-260.

7. Подымова С. А. Болезни печени : руководство / С. А. Подымова. - 4е изА. - М., 2005.

8. Рахимова О. Ю. Варианты поражения почек при болезни Вильсона / О. Ю. Рахимова // Терапевт. архив. - 2004. - № 9. - С. 88-91.

9. Сосудистая пурпура и синдром Гийена - Барре при тяжелом течении болезни Вильсона - Коновалова / Т. П. Разина, О. Ю. Рахимова, Е. А. Арион [и Ар.] // Клин, меА. -2005 . - № 6. - С. 80-83.

10. Ференци П. Гемохроматоз и болезнь Вильсона / П. Ференци // Российск. журн. гастроэнтерол., гепатол. и колопроктол. - 2001. - № 4. - С. 64-67.

11. Фиброзирующий альвеолит, как осложнение терапии D-пеницимамином при болезни Вильсона / О. Ю. Рахимова, Т. П. Розина, Е. Н. Попова [и Ар.] // Клин. меА. - 2004. - № 11. - С. 57-60.

12. Циммерман Я. С. Классификации гастроэнтерологических заболеваний и киинических синдромов / Я. С. Циммерман, И. Я. Циммерман. - 4-е расшир. и перераб. изА. - Пермь, 2014. - С. 131-132.

13. Циммерман Я. С. Терминологические проблемы в гастроэнтерологии / Я. С. Циммерман // Рос. журн. гастроэнтерол., гепатол. и колопроктол. 1996. - № 4. - C. 6-10.

14. Шерлок Ш. Заболевания печени и желчных путей / Ш. Шерлок, Аж. Аули; пер. с англ. - М., 1999. - 859 с.

15. Clinical differentiation of fulminant Wilson's hepatitis from other causes of hepatic failure / D. H. Berman, R. I. Leventhal, J. S. Gavaler [et al.] // Gastroenterology. - 1991. - Vol. 100. - P. 1129-1134.

16. Gollan J. L. Wilson disease in 1998: genetic, diagnostic and therapeutic aspects / J. L. Gollan, J. G. Gollan // Hepatology. - 1998. - Vol. 28. - P. 28-36.
17. Harma M. Human herpes-virus-VI and acute liver failure / M. Harma, K. Hockerstedt, I. Lautenschlager // Transplantation. - 2003. - Vol. 76, No 3. - P. 536539.

18. Human copper-transporting ATPase ATP7B (the Wilsons disease protein): biochemical properties and regulation / S. Lutsenko, R. G. Efremov, R. Tsivkovskij, J. M. Walker // J. Bioenerg. Biomembr. - 2002. Vol. 34, No 5. - P. 351-362.

19. An international symposium on Wilson's and Monkes diseases / P. Ferenci, T. C. Gillian, J. D. Gitlin [et al.] // Hepatology. - 1996. - Vol. 24. - P. 952- 958.

20. Leiber B. Die klinischen Syndrome / B. Leiber, G. Olbrich. - Munchen ; Berlin-Wien, 1966.

21. Matsumura A. Plasma exchange for hemolytic crisis in Wilson disease / A. Matsumura, H. Hiraishi, A. Terano // Ann. Int. Med. - 1999. - Vol. 131, No 11. - P. 866-868.

22. Prevalence of herpes-viridae and hepatitis $E$ virus DNA in the liver of patients with non-A, non-B fulminant hepatic failure / A. Mason, R. Sallie, P. Perillo [et al.] // Hepatology. - 1996. - Vol. 24, No 6. - P. 1361-1365.

23. Roberts E. A. A practice guideline in Wilson's disease / E. A. Roberts // Hepatology. - 2003. - Vol. 37, No 6. P. $1475-1492$.

24. Role of gancyclovir and HAART administration in the treatment of a rare complication of HIV disease: cytomegalovirus-associated Gillain -Barre syndrome / L. Calza, R. Manfredi, G. Marinacci [et al.] // J. Chemother. - 2001. - Vol. 13, No 5. - P. 575-577.

25. Schiff's Diseases of the Liver. $-8^{\text {th }}$ ed. - Philadelphia; New-York, 1999. - P. 1091-1106.

26. Sternlieb I. D-penicillamine induced Goodpasture's syndrome in Wilson disease / I. Sternlieb, B. Bennett, I. H. Scheinberg // Ann. Intern. Med. - 1975. Vol. 82. - P. 673-675.

27. Sternlieb I. Prospectives on Wilsons disease / I. Sternlieb // Hepatology. - 1999. - Vol. 12. P. 1234-1239.

28. Tao T. Y. Hepatic copper metabolism insighis from genetic Aiseese / T. Y. Tao, J. D. Giflin // Hepatology. 2003. - Vol. 37, No 6. - P. 1241-1242.

29. Wilsons disease associated with olfactory paranoid syndrome and idiopathic thrombocytopenic purpura / M. Segawa, M. Tacao, S. Nogawa [et al.] // No. To. Shinkei. - 2003. - Vol. 55, No 10. - P. 899-902.

30. Wilsons disease in patients presenting with liver disease: a diagnostic challenge / P. Steindl, P. Ferenci, H. P. Dienes [et al.] // Gastroenterology. - 1997. Vol. 113. - P. 2012-2018.

31. Wilsons disease with HCV-infections / A. Halecz, J. Socha, A. Czlonkowska, J. Gajda // Radiatr. Pol. 1995. - Vol. 70, No 5. - P. 431-435. 


\section{RU Болезнь Вильсона - гепатоцеребральная Аистрофия}

\section{Я. С. Циммерман}

Пермский государственный медицинский университет им. акаА. Е. А. Вагнера, Пермь, Россия

Киючевые слова: болезнь Вильсона (гепатоцеребральная Аистрофия), Аефиниция, этиология, патогенез, Аиагностика, лечение

В статье представлен подробный обзор современных представлений о болезни Вильсона - гепатоцеребральной Аистрофии. Изложены определение, терминология, история изучения заболевания. Большое внимание удемено разбору патогенеза гепатоцеребральной Аистрофии, в том числе генетической основе ее развития, нарушениям обмена меди. Тщательно описана кминика с учетом особенностей поражения печени и внепеченочных проявлений, Аиагностика, классификация. Особое внимание уделено средствам патогенетического и симптоматического мечения.

\section{EN Wilson's disease - hepatocerebral dystrophy}

\section{Y. S. Tsimmerman}

Perm State Medical University n. a. E. A. Vagner, Perm, Russia

Key words: Wilson's disease (hepatocerebral dystrophy), definition, etiology, pathogenesis, diagnosis, treatment

The article presents a detailed review of modern ideas on Wilson's disease - hepatocerebral dystrophy. The definition, terminology, history of the study of the disease are stated. Special attention is paid to the analysis of the pathogenesis of hepatocerebral dystrophy, including the genetic basis of its development, the disturbance of copper metabolism. The clinical picture is thoroughly described, taking into account the characteristics of liver lesion and extrahepatic manifestations, diagnostics, classification. Particular attention is paid to the means of pathogenetic and symptomatic treatment.

\section{UA Хвороба Ві^ьсона - гепатоцеребральна Аистрофія}

\section{Я. С. Циммерман}

Пермський державний медичний університет ім. акаА. $€$ Є. А. Вагнера, Перм, Росія

Киючові слова: хвороба Вільсона (гепатоцеребральна Аистрофія), Аефініція, етіологія, патогенез, Аіагностика, лікування

У статті представлений Аетальний огляА сучасних уявлень про хворобу Вільсона - гепатоцеребральну Аистрофію. Викладені визначення, термінологія, історія вивчення захворювання. Велику увагу приді^ено розбору патогенезу гепатоцеребральної Аистрофії, зокрема генетичній основі ії розвитку, порушенням обміну міді. Ретельно описана клініка з урахуванням особливостей ураження печінки і позапечінкових проявів, Аіагностика, класифікація. Особливу увагу приділено засобам патогенетичного та симптоматичного мікування. 